\title{
Ammonia thiosulfate in Japanese plum tree thinning
}

\author{
Ricardo Antonio Ayub ${ }^{1}$, Iohann Metzger Bauchrowitz ${ }^{2}$, Clandio Medeiros da Silva ${ }^{3}$ \\ Isabela Leticia Pessenti ${ }^{4}$, Fernanda Grimaldi ${ }^{5}$, André Belmont Pereira ${ }^{6}$
}

\begin{abstract}
In order to test the use of ammonia thiosulfate (ATS) in the chemical thinning of the Japanese plum tree, a field experiment was conducted throughout the 2015/2016 and 2016/2017 crop growing seasons at Ponta Grossa, PR, Brazil. The experimental design adopted herein was a randomized block design (RBD). During the 2015/2016 season, the trial was comprised of two accesses and six treatments, such as T1 (control); T2 (ATS 4\%); T3 (ATS 5\%); T4 (ATS 6\%); T5 (ATS 7\%) and T6 (manual thinning) with four replications. During the 2016/2017 season, solely one plum tree access was taken into account along with six treatments, such as T1 (control); T2 (ATS 6\%); T3 (ATS 7\%); T4 (ATS 8\%); T5 (ATS 9\%) and T6 (manual thinning) and four replications. The evaluations were performed seven days before the application of ATS and 30 days before harvest to establish the percentage of fruit drop. The following response variables were assessed: diameter (D), fresh mass (MF), firmness (N), soluble solids (SS), titratable acidity (AT), ratio, $\mathrm{pH}$ and plant production (PP). Experimental data were compared by means of the Tukey test at 5\% probability. The concentration of $8 \%$ ATS was efficient in the chemical thinning of the Japanese plum fruits, having a diameter and productivity similar to the manual thinning, evidencing that such a product was amenable to enhance commercial fruit quality.
\end{abstract}

Index terms: Prunus salicina, flowering, chemical.

\section{Tiossulfato de amônia no raleio de ameixa japonesa}

\section{Corresponding author:} rayub@uepg.br

Received: March 07, 2019 Accepted: August 16, 2019

Copyright: All the contents of this journal, except where otherwise noted, is licensed under a Creative Commons Attribution License.

\section{$(\mathrm{cc}) \mathbf{\mathrm { EY }}$}

Resumo- $\mathrm{O}$ manejo da cultura da ameixeira apresenta grandes problemas no Brasil devido à falta de produtos químicos registrados para o uso na cultura. Com o objetivo de testar o emprego do Tiossulfato de amônio (ATS) no raleio químico da ameixa japonesa implantou-se e conduziu-se um experimento durante as safras de 2015/2016 e 2016/2017 em Ponta-Grossa, PR, Brasil. O delineamento experimental utilizado foi em DBC (delineamento em blocos casualizados). Na safra 2015/2016 o experimento foi composto por dois acessos e seis tratamentos, T1 (controle), T2 (ATS 4\%), T3 (ATS 5\%); T4 (ATS 6\%), T5 (ATS 7\%), T6 (raleio manual) com quatro repetições. Durante a safra de 2016/2017, o estudo foi composto por um acesso de ameixeira com seis tratamento, T1 (controle), T2 (ATS 6\%), T3 (ATS 7\%), T4 (ATS 8\%), T5 (ATS 9\%), T6 (raleio manual) e quatro repetições. As avaliações foram realizadas sete dias antes da aplicação do ATS e 30 dias antes da colheita para estabelecer a porcentagem de queda de frutos da planta. Foram analisados o diâmetro, massa fresca (MF), firmeza (N), sólidos solúveis (SS), acidez titulável (AT), ratio, $\mathrm{pH}$ dos frutos e produção por planta (PP). Os dados foram analisados através do teste de Tukey a $5 \%$ de probabilidade. A concentração de $8 \%$ de ATS foi eficiente no raleio químico para a ameixa japonesa, tendo diâmetro e produtividade similar ao raleio manual, sendo um bom produto para melhorar a qualidade comercial da fruta.

Termos para indexação: Prunus salicina, floração, químico.

${ }^{1} \mathrm{PhD}$ Professor in Crop Science Department, State University of Ponta Grossa (UEPG), Ponta Grossa-PR, Brazil. E-mail: rayub@uepg.br ${ }^{\text {(ORcID }}$ 0000-0003-3240-8417)

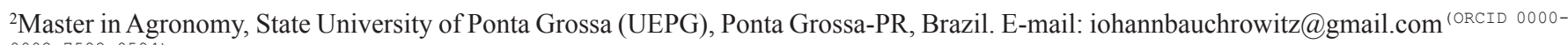
$0002-7582-0594)$

${ }^{3} \mathrm{PhD}$ in Agronomy. Paraná Agronomic Institute, Londrina-PR, Brazil. E-mail: clandio@iapar.br(0RCID 000-0002-0569-4836)

${ }^{4} \mathrm{PhD}$ Student in Agronomy, State University of Ponta Grossa (UEPG), Ponta Grossa-PR, Brazil. E-mail:isabelaleticiapessenti@gmail.com (ORCID 0000-0002-5176-3134)

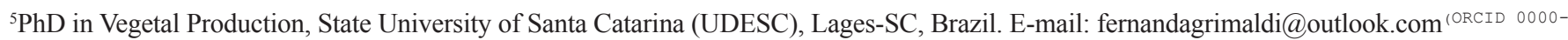
0002-2632-9328)

${ }^{6} \mathrm{PhD}$ Professor in Soil Department, State University of Ponta Grossa (UEPG), Ponta Grossa-PR, Brazil. E-mail: abelmont@uepg.br(ORcid 0000-0002-1673-9841) 


\section{Introduction}

The plum is a temperate fruit tree that has a great potential for growth in Brazil (FACHINELLO et al., 2011). However, the producers have been facing problems, such as high cost of labor, shortages for handling and harvest (PAVANELLO; AYUB, 2014). Manual thinning is a very costly practice and hard to execute in large fields, making it a non-viable option for producers (SCHRÖDER, 2013), increasing the production cost (AHRENS et al., 2014). Due to lack of skilled labor, thinning has been replaced by chemicals (MCARTNEY; OBERMILLER, 2012).

Nowadays, products such as Ethephon (PAVANELLO, AYUB, 2012), ATS and hydrogen cyanamide (ANZANELLO; TEDESCO, 2017; PAVANELLO; ZOTH; AYUB, 2018) are used for crops such as the European plum (WEBSTER; SPENCER, 2000; PAVANELLO; AYUB, 2014) and apple trees (HAMPSON; BEDFORD, 2011; BOUND; WILSON, 2007). These products are employed mainly in the European continent, where the need for manual thinning is minimal owing to chemicals usage (SEEHUBER; DAMEROW; BLANKE, 2011).

ATS decreased the rate of pollen germination, pollen tube length, due to its high sulfur concentration (BOUND; WILSON, 2007), which struggles the ovule fertilization (MARCHIORETTO et al., 2018), the desiccation of flowers and damage to the base of the flower peduncle (MELAND; MAAS, 2017). Since it is a leaf fertilizer, it does not present risk to the environment (BALKHOVEN-BAART; WERTHEIM, 1998). In the United States and Europe, ATS use is consolidated and there are plenty of research on this theme. In Brazil, however, little is known about the thinning properties and its effects on fruit quality parameters and chemical blossom thinner (MARCHIORETTO et al., 2018). Thus, the aim of the current research was to assess the effect of ATS different concentrations as a chemical thinning process throughout two crop growing seasons in distinct accesses of Japanese plum.

\section{Material and methods}

The experiment was carried out in Ponta Grossa,

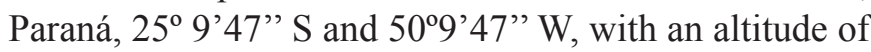
approximately $838 \mathrm{~m}$. The climate of the region according to the Köppen classification is of type $\mathrm{Cfb}$, subtropical humid, with an annual mean temperature of $18{ }^{\circ} \mathrm{C}$ plus an overall annual precipitation of roughly $1.550 \mathrm{~mm}$ (CAVIGLIONE et al., 2000).

During the 2015/2016 season, the experiment was conducted in RBD, comprised by G52 precocious and G7 later-on plum selections and six treatments with four replications, with five plants each. The treatments were T1 (control), T2 (ATS 4\%), T3 (ATS 5\%), T4 (ATS 6\%), T5 (ATS 7\%), T6 (manual thinning). ATS $(25 \% \mathrm{~S}$ and $11 \%$ $\mathrm{N}, 1040 \mathrm{~L} \mathrm{ha}^{-1}$ ) was applied with $50 \%$ open flowers in the morning in mid-July, at $15^{\circ} \mathrm{C}$ by means of a manual costal spray. During the $2016 / 2017$ season, G53 one lateron access was taken into account and the experiment was conducted in RBD in light of six treatments T1 (control), T2 (ATS 6\%), T3 (ATS 7\%), T4 (ATS 8\%), T5 (ATS 9\%), T6 (manual thinning), with four replications, composed by five plants.

In each cycle, 200 flowers/plant were marked seven days before the ATS application, and were counted 30 days before fruit harvest to define the percentage of flower drop. After harvest, 120 fruits were taken to the laboratory where the physical chemical analyses were performed. The fruit harvesting point was between 25 and $50 \%$ of red color.

The physical analysis of diameter $(\mathrm{mm})$, fruit fresh mass (FM) (g), firmness $(\mathrm{N})$, soluble solids (SS) ( ${ }^{\circ}$ Brix), titratable acidity (AT) (\% malic acid), ratio (SS/ $\mathrm{AT}$ ), $\mathrm{pH}$ and plant production (PP) were based upon the methodology proposed by Pavanello and Ayub (2012). The experimental data were submitted to a polynomial regression analysis (data not shown herein) and the treatment means were compared by the Tukey test at 5\% reliability by means of SISVAR 5.6 program (FERREIRA, 2014).

\section{Results and discussion}

Manual thinning was equivalent to $7 \%$ ATS with $60 \%$ flower drop, $50 \%$ more than control (Fig. 1a) during 2015/16 season. This allowed to reach $48 \mathrm{~mm}$ of fruit diameter for the concentrations 6 and $7 \%$ in the accesses G52 and G7 (Fig. 1b) throughout this season. Thus, it resulted in fruits with a mean of fruit fresh mass of $60 \mathrm{~g}$ for $\mathrm{G} 7$ access, which led to values of $10 \mathrm{~g}$ up above those related to control treatment, although not revealing statistical differences (Fig.1c). For G52 access, fresh mass was lower when compared to G7 among ATS concentrations (Fig.1c).

It was observed that PP decreased 10 to $7.5 \mathrm{~kg}$ in comparison to manual thinning, but not bringing about significant discrepancies among ATS concentrations (Fig. 1d) during 2015/16 season. However, the commercial yield improved by increasing the caliber of the fruit. Throughout 2016/2017 season, G53 access flower drop reached approximately $60 \%$ in manual thinning with 9\% ATS concentration, despite of not being statistically different from 8\% concentration (Fig. 2a) during 2016/17 season and statistically superior than natural drop, which resulted in $15 \%$ flower drop under control treatment conditions. 
Nevertheless, there was an increase in diameter, achieving 46 and $47 \mathrm{~mm}$ for both manual and 8 - 9\% ATS concentrations (Fig. 2b) during 2016/17, not differing from ATS concentrations of 6 and $7 \%$ with a diameter of $44 \mathrm{~mm}$ (Fig. 2b). The fruit FM increased with manual thinning, but with effects not statistically different from the higher concentrations of ATS, leading to weight of fruits above $50 \mathrm{~g}$ (Fig. 2c) during such a crop growing season, that was superior to the control and 6\% ATS treatment. This is due to the fact that ATS is a foliar fertilizer, which helps fruit development within an optimum of physiological efficiency. The yield per plant is lower in manual thinning, even though there are no significant differences among the highest doses of ATS, with production ranging between 20 and $26 \mathrm{~kg}$ / plant (Fig. 2d) during the 2016/17 season.

Sulfur-based products may influence flowers drop and fruits on different fruit plants (BANGERTH, 2004). Owing to ATS composition possessing great amount of sulfur when applied to blossoming, such a product causes flower burning and consequently the abscission of the flowers. This reduces the plum number (PAVANELLO; ZOTH; AYUB, 2018) and increases apple diameter (ROBINSON; LAKSO, 2008). In apple cv. Fuji, which received three applications of ATS with $12 \mathrm{~kg}$ i.a./ha during flowering, there was a flower reduction corresponding to $82 \%$ (MAAS, 2007). According to Petri et al. (2016), the concentration of 1.5 to $2 \%$ of ATS is sufficient to thin apple trees, which is a very low concentration for the Europe plum tree (PAVANELLO; ZOTH; AYUB, 2018), corroborating the outcomes obtained in our current study on Japanese plum.

For the variables SS, AT, ratio, $\mathrm{pH}$ and firmness for G52 and G3 accesses there were not significant differences among treatments (data not shown). However, for the G7 access there were chemical and physical discrepancies among treatments not solely attributed to the influence of ATS application, but rather to a likely sample variation inherent to the trial (Table 1).

The G52 and G7 approaches treated with concentrations of 6 and 7\% of ATS and with manual thinning resulted in a fruit diameter greater than $46 \mathrm{~mm}$. Such a fruit diameter is considered to be higher than the 40-mm obtained for cultivar Irati, which was treated with ethephon (PAVANELLO, AYUB, 2012), as well as thresholds of 45.80 and $45.90 \mathrm{~mm}$ for cultivar Polirosa subjected to green pruning (CARVALHO et al., 2015). Fruits of the G53 access thinned under concentrations of $8-9 \%$ of ATS presented fruits with a diameter of $46.95 \mathrm{~mm}$, being superior to the manual thinning of this access (Fig. 2b). Fruits with a diameter greater than 44 $\mathrm{mm}$ are accepted for commercialization (PAVANELLO; AYUB, 2012; AHRENS et al., 2014). The increase in the plum diameter was proportional to the increase of ATS concentrations, due to the reduction of the excess fruit produced in the accesses, as observed under the mechanical (HEHNEN et al., 2012) and chemical thinning (PAVANELLO, AYUB, 2012, PAVANELLO; ZOTH; AYUB, 2018). The composition of the ATS has a fertilizing effect, mainly having nutrients such as sulfur and nitrogen (FERNANDES, 2010), which when applied to flowering causes an increase in apple diameter of 10 to $12 \mathrm{~mm}$ (MAAS, 2007).

The FM increased with raises in ATS concentration, reaching 52.25 and $58.79 \mathrm{~g}$ at G52 and G7 accesses respectively, whereas at G53 access the best fresh mass results were obtained under a concentration of $8 \%$ leading to a weight of fruits equivalent to $64.67 \mathrm{~g}$. Fruits of cultivars Reubennel and Irati have shown a fresh mass of 64 and 40g per fruit (PAVANELLO; AYUB 2014).

This is the first report dealing with ATS use on Japanese plum in Brazil. Previous studies carried out with European plums under the influence of 3\% ATS concentrations during full blooming did not culminate to thinning satisfactory results (Pavanello et al., 2018). Recent research taking into consideration ethephon on physiological responsiveness of fruit plants have had a consistent impact on thinning (PAVANELLO \& AYUB, 2012, 2014), however such a product did not evidence permission of application in plum orchards at commercial scales. For Maxi Gala apple Marchioretto et al. (2018) observed that ATS at $2.5 \%$ is effective to reduce crop load and improve fruit quality. The aforementioned authors reported that ATS thinning effect is not dependent on weather conditions throughout the crop growing season, an assumption that opposes the findings of Fallahi \& Greene (2010) in conjunction with our personal information.

In stone fruits blossoms thinners should be sprayed whenever some, but not all blossoms are fertilized (FALLAHI and WILLEMSEN, 2002). In peaches ATS concentration at $5 \%$ caused excessive thinning and reduced crop value whereas 3.5\% ATS provided less thinning and resulted in the highest crop value (OSBORNE; ROBINSON; PARRA-QUEZADA; 2006). Trials conducted in Britain on the plum cultivar Victoria demonstrated that ATS applied at $1.5 \%$ active ingredient at high volume sprays (1000 1 ha-1) was very effective for flower thinning. At such a concentration little or no damage at all was noticed on the leaves and/or wood of the cultivar under scrutiny (WEBSTER e SPENCER, 2000). However, the flowers of Victoria develop quite well in advance of the spur leaves and whenever sprays to those cultivars whose spur leaves happen to develop at the same time of flower opening damage is more conspicuous leading to financial losses. In this way, the current work shows labor and production cost reductions in plum cultivation, as described by AHRENS, ET AL. (2014). 
Table 1 - Soluble solids, titratable acidity, ratio, $\mathrm{pH}$ and firmness in the G7 access of Japanese plum trees treated with ammonium thiosulfate at full blooming during the 2015/2016 season. (Ponta Grossa, 2018).

\begin{tabular}{cccccc}
\hline & $\begin{array}{c}\mathrm{SS} \\
\left({ }^{\circ} \mathrm{brix}\right)\end{array}$ & $\begin{array}{c}\mathrm{AT} \\
(\% \text { malic acid })\end{array}$ & $\begin{array}{c}\text { Ratio } \\
(\mathrm{SS} / \mathrm{AT})\end{array}$ & $\mathrm{pH}$ & $\begin{array}{c}\text { Firmness } \\
(\mathrm{N})\end{array}$ \\
\hline Control & $11,18 \mathrm{ab}$ & $0,81 \mathrm{ab}$ & $13,81 \mathrm{bc}$ & $3,42 \mathrm{ab}$ & $8,78 \mathrm{~b}$ \\
$4 \%$ & $12,13 \mathrm{ab}$ & $0,83 \mathrm{ab}$ & $14,57 \mathrm{bc}$ & $3,11 \mathrm{ab}$ & $14,20 \mathrm{a}$ \\
$5 \%$ & $8,53 \mathrm{~b}$ & $1,31 \mathrm{a}$ & $12,31 \mathrm{c}$ & $2,65 \mathrm{~b}$ & $14,92 \mathrm{a}$ \\
$6 \%$ & $11,66 \mathrm{ab}$ & $0,68 \mathrm{ab}$ & $17,20 \mathrm{bc}$ & $3,14 \mathrm{ab}$ & $9,34 \mathrm{~b}$ \\
$7 \%$ & $12,75 \mathrm{a}$ & $0,67 \mathrm{ab}$ & $19,14 \mathrm{~b}$ & $3,47 \mathrm{ab}$ & $8,47 \mathrm{~b}$ \\
Hand Thinning & $12,36 \mathrm{a}$ & $0,48 \mathrm{~b}$ & $25,91 \mathrm{a}$ & $4,00 \mathrm{a}$ & $8,41 \mathrm{~b}$ \\
\hline CV $(\%)$ & 14,79 & 45,58 & 16,84 & 13,59 & 16,31
\end{tabular}

* Means followed by the same letters in the column do not differ from one another by Tukey test $(\mathrm{p} \leq 0.05)$.
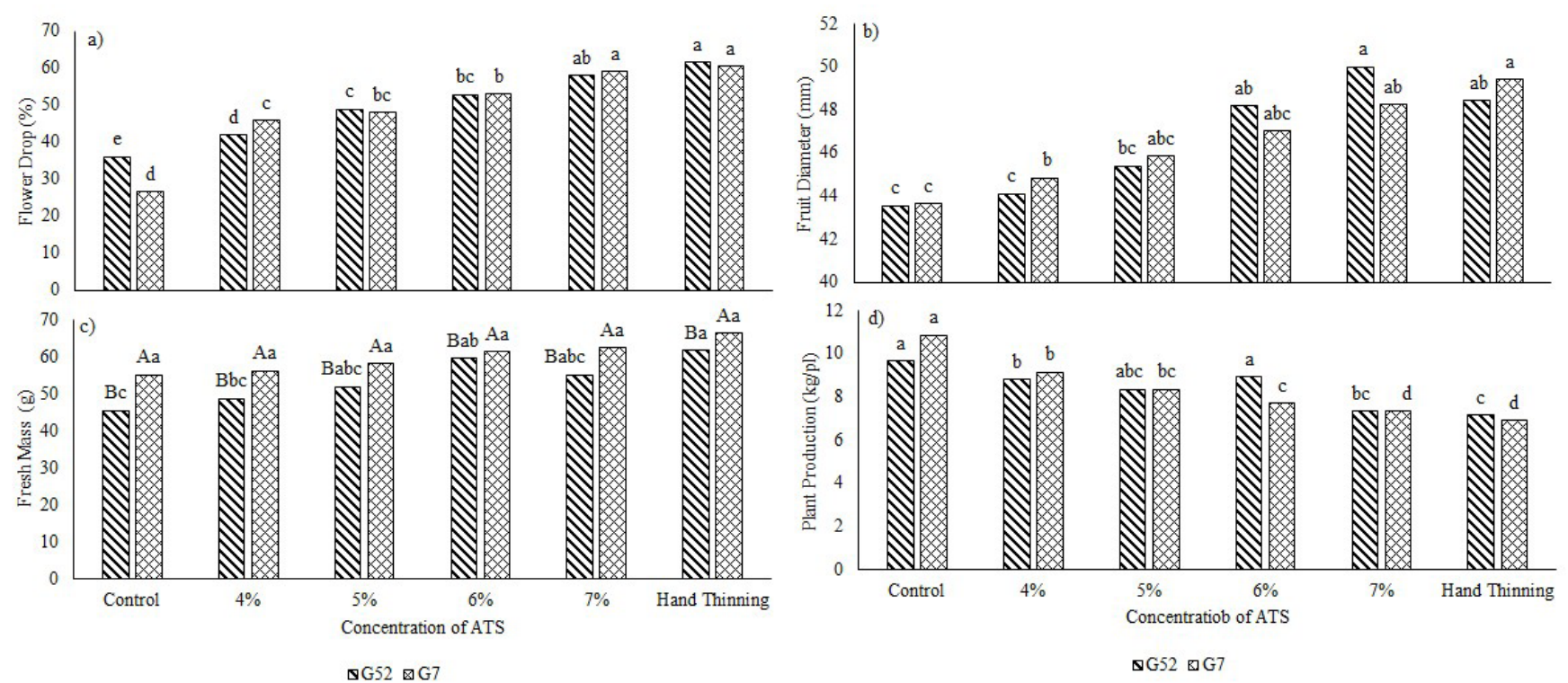

Figure 1 - Flower drop (\%) (a), fruit diameter ( $\mathrm{mm}$ ) (b), fresh mass (g) (c) and plant production ( $\mathrm{kg} / \mathrm{pl}$ ) of Japanese plum accesses G52 and G7 submitted to different concentrations of ATS during the 2015/2016 season. Means followed by the same letters do not differ statistically from one another; capital letters between accesses and small letters between concentrations by the Tukey test $(\mathrm{p} \leq 0.05)$. Figures $1 \mathrm{a}, \mathrm{b}$ and $\mathrm{c}$ do not differ statically between treatments of access. Ponta Grossa (2018). 

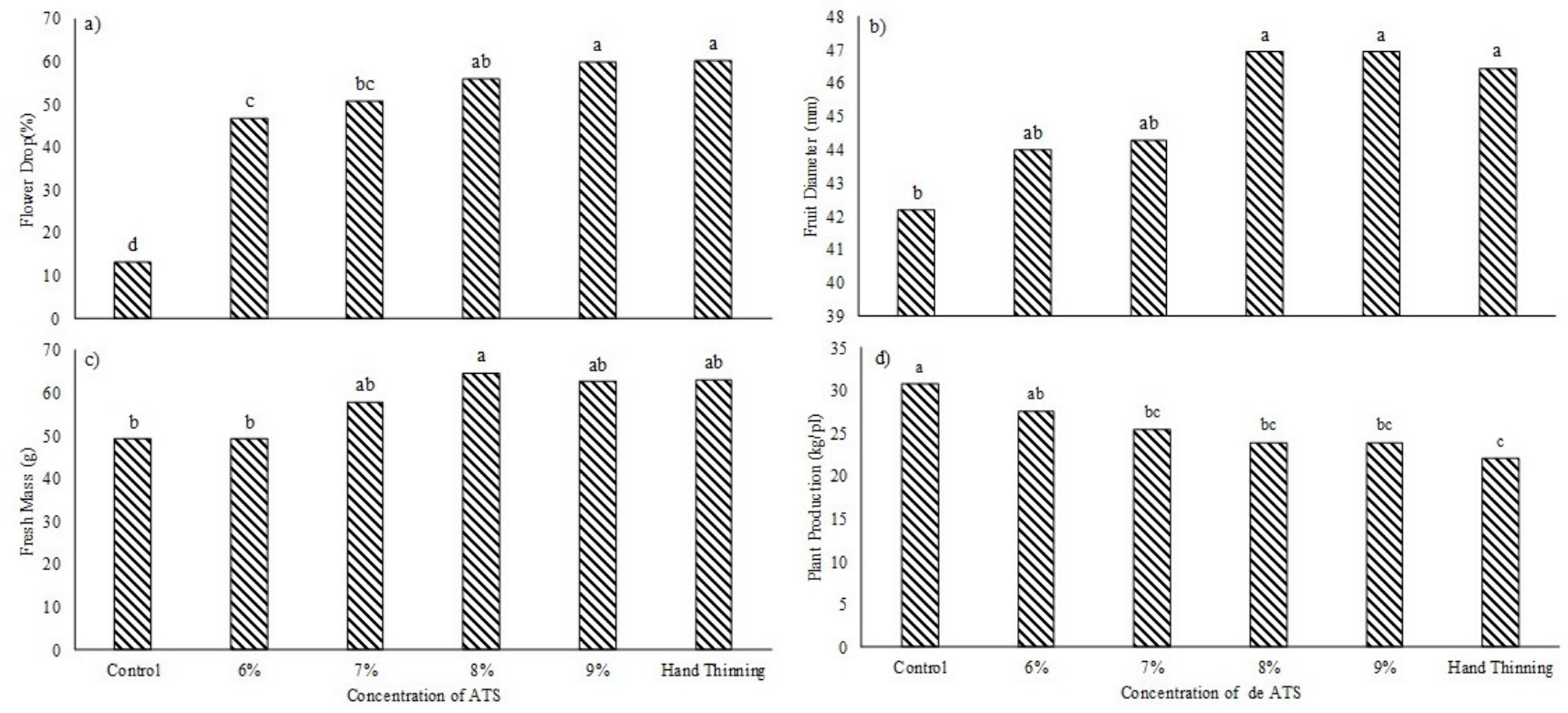

Figure 2 - Flower drop (\%) (a), fruit diameter (mm) (b), fresh mass (g) (c) and plant production (kg / pl) of Japanese plum access G53 submitted to different concentrations of ATS during the 2016/2017 season. Means followed by the same letter do not differ statistically by the Tukey test ( $\mathrm{p} \leq 0.05)$. Ponta Grossa (2018).

\section{Conclusions}

The accesses under scrutiny have a large potential to meet expectations of the market because by the adoption of a good management of the orchards they reach both fresh weight and caliber at a commercial scale.

It is pivotal to consider that the concentration of $7 \%$ ATS during the first season did not reach the maximum point of thinning. However, throughout the second season the concentration of $8 \%$ ATS was proved to be efficient to trigger chemical thinning on Japanese plums, causing the fruit to enhance diameter and fresh mass, as well as to achieve potential yield equivalent to that one obtained by means of manual thinning procedure. ATS was found to be a good product amenable to assure economical returns, improve commercial fruit quality and reduce labor costs in the field.

\section{References}

AHRENS, R. de B.; PAVANELLO, A.P.; AHREN, D.C.; FRANCISCO, A.C. de; AYUB, R.A. Análise econômica do raleio químico e manual em ameixeiras. Interciencia, Caracas, v.39, n.10, p.723-726, 2014.

ANZANELLO, R.; TEDESCO, A. Chemical thinning of flowers and fruits of the peach cultivar Coral with hydrogen cyanamide. Ciência Rural, Santa Maria, v.47, n. 10, 2017.
BALKHOVEN-BAART, J.; WERTHEIM, S. Thinning response of Elstar apple to the flower thinner ammonium thiosulphate (ATS). Acta Horticulturae, The Hague, v.463, p.481-483, 1998.

BANGERTH, F. Internal Regulation of Fruit Growth and Abscission (Keynote). Acta Horticulturae, The Hague, v.636, p.235-248, 2004.

BOUND, S.; WILSON, S. Ammonium thiosulfate and 6-benzyladenine improve the crop load and fruit quality of 'Delicious' apples. Australian Journal of Experimental Agriculture, Melbourne, v.47, n.5, p.635-644, 2007.

CARVALHO, R.I.N. de; SORRENTI, G.; PEREIRA, G.P.; VENDRAMIM, D.W.; OLIVEIRA, R. de F.; KUSSLER, R.E. Poda verde e qualidade do fruto da ameixeira em alta densidade. Revista Eletrônica Científica da UERGS, Bajé, v.1, n.1, p.69-73, 2015.

CAVIGLIONE, J.H.; KIJHL, L.R.B.; CARAMORI, P.H.; GIACOMINI, C.C. Cartas climáticas do Paraná.

Versao 1.0. Londrina: Instituto Agronómico do Paraná, 2000.

FACHINELLO, J.C.; PASA, M.S.; SCHMTIZ, J.D.; BETEMPS, D.L. Situação e perspectivas da fruticultura de clima temperado no Brasil. Revista Brasileira de Fruticultura, Jaboticabal, v.33, n.1, p.109-120, 2011. 
FALLAHI, E.; GREENE, D. W. The impact of blossom and postbloom thinners on fruit set and fruit quality in apples and stone fruits. Acta Horticulturae, The Hague, v.884, p.179-188, 2010.

FALLAHI, E.; WILLEMSEN, K.M. Blossom thinning of pome and stone fruit. HortScience, Alexandria, v.37, n.3, p.474-477, 2002.

FERNANDES, C.M.C. Monda em macieira Fuji. Comparação entre novas substâncias quimicas e a monda manual. 2010. Dissertação (Mestrado em Engenharia Agronómica - Hortofruticultura e Viticultura) - Instituto Superior de Agronomia, Lisboa, 2010.

FERREIRA, D. F. Sisvar: a Guide for its Bootstrap procedures in multiple comparisons. Ciência e Agrotecnologia, Lavras, v.38, n.2, p.109-112, 2014.

HAMPSON, C.; BEDFORD, K. Efficacy of blossom thinning treatments to reduce fruit set and increase fruit size of Ambrosia and Aurora Golden Gala ${ }^{\mathrm{TM}}$ apples. Canadian Journal of Plant Science, Ottawa, v.91, n.6, p.983-990, 2011.

HEHNEN, D.; LEWIS, K.; FERSON, J.Mc.; BLANKE, M. Mechanical flower thinning improves fruit quality of apples and promotes consistent bearing. Scientia Horticulturae, New York, v.134, p.241-244, 2012.

MAAS, F. Thinning strategies for'Elstar'applesexperiences with ammonium thiosulphate, calcium hydroxide and benzyladenine. Erwerbs-Obstbau, Berlin, v.49, n.3, p.101-105, 2007.

MARCHIORETTO, Lucas De Ross et al. Ammonium thiosulfate as blossom thinner in'Maxi Gala'apple trees. Pesquisa Agropecuária Brasileira, Brasília, DF, v.53, n.10, p.1132-1139, 2018.

MCARTNEY, S.J.; OBERMILLER, J.D. Use of 1-aminocyclopropane carboxylic acid and metamitron for delayed thinning of apple fruit. HortScience, Alexandria, v.47, n.11, p.1612-1616, 2012.
NEVES, A.A.; BETTIOL NETO, J.; BARBOSA, W.; CHAGAS, P.C.; CIA, P.; SANCHES, J.; CARVALHO, A.S.; PIO, R., CHAGAS, E.A. Avaliação vegetativa e fenológica de cultivares de ameixeira. Anais Pibic, Belém, v.1, n.1, p.1-6, 2009.

OSBORNE, J.L.; ROBINSON, T.L.; PARRA-QUEZADA, R. Chemical blossom thinning agents reduce crop load of rising star peach in New York. Acta Horticulturae, The Hague, v.727, p.423-428, 2006.

PAVANELLO, A.P.; AYUB, R.A. Aplicação de ethephon no raleio químico de ameixeira e seu efeito sobre a produtividade. Revista Brasileira de Fruticultura, Jaboticabal, v.34, n.1, p.309-316, 2012.

PAVANELLO, A.P.; AYUB, R.A. Chemical thinning of plum fruits with ethephon. Ciência Rural, Santa Maria, v.44, n.10, p.1766-1769, 2014.

PAVANELLO, A.P.; ZOTH, M.; AYUB, R.A. Manage of crop load to improve fruit quality in plums. Revista Brasileira de Fruticultura, Jaboticabal, v.40, n.4, e-721, 2018. Número especial

PETRI, J.L; HAWERROTH, F.J.; LEITE, G.B.; SEZERINO, A.A.; COUTO, M. Reguladores de crescimento para frutíferas de clima temperado. Bento Gonçalves: Embrapa Uva e Vinho, 2016.

ROBINSON, T.; LAKSO, A. N. Predicting chemical thinner response with a carbohydrate model. Acta Horticulturae, The Hague, v.903, p.743-750, 2011

SCHRÖDER, M. Correlative polar auxin transport to explain the thinning mode of action of benzyladenine on apple. Scientia Horticulturae, New York, v.153, p.8492, 2013.

SEEHUBER, C.; DAMEROW, L.; BLANKE, M. Regulation of source: sink relationship, fruit set, fruit growth and fruit quality in European plum (Prunus domestica L.) - using thinning for crop load management. Plant Growth Regulation, Dordrecht, v.65, n.2, p.335341, 2011.

WEBSTER, A.; SPENCER, J. Fruit thinning plums and apricots. Plant Growth Regulation, Dordrecht, v.31, n.1/2, p.101-112, 2000. 


\section{Erratum of article:}

Ayub, Ricardo Antonio, Bauchrowitz, Iohann Metzger, Silva, Clandio Medeiros da, Pessenti, Isabela Leticia, Grimaldi, Fernanda, \& Perira, André Belmont. (2019). Ammonia thiosulfate in Japanese plum tree thinning. Revista Brasileira de Fruticultura, 41(5): e-543 https://dx.doi.org/10.1590/0100-29452019543

In the page 1: Authors' name

where it reads:

André Belmont Perira

should read:

André Belmont Pereira 